\title{
THE HISTORICAL PHENOMENON OF PHILANTHROPY IN EUROPEAN COUNTRIES (ON THE EXAMPLE OF GERMANY)
}

\author{
Abdulazizbek Fahriddin Ugli Utkirov
}

2nd-Year Student, Historical Faculty, Tashkent State Pedagogical University

\section{ABSTRACT}

This article is devoted to the reformation of charity and charitable societies in Germany. The subject is the study of the formation and development of charity in Germany under the influence of socio-economic and cultural-historical factors.

KEYWORDS: - German Democratic Republic, edict, subject of charity, Sozialhilfe, provision, Sozialamt.

\section{INTRODUCTION}

The purpose of the research is to identify the specifics of modern charitable activity in the context of its historical development, theoretical interpretation and practical experience.

The date of the entry of the German Democratic Republic into the Federal Republic of Germany October 3, 1990-is considered to be the beginning of the history of modern Germany. From the point of view of constitutional law, the five former lands of the GDR became constituent parts of the Federal Republic of Germany. The unification of Germany did not lead to the creation of a new state. The GDR ceased to exist as a subject of international law, and the FRG, while continuing to exist as such, increased its territory and population. Germany today is a highly developed European state, a member of the" Big Seven", a member of the European Union. The Basic Law of the Federal Republic of
Germany (dated May 23, 1949) is the fourth Constitution in the history of Germany (before that, Constitutions were adopted in 1849, 1871, and 1919). The right to social assistance was enshrined in the German Constitution of 1919. According to the Constitution, the Federal Republic of Germany is defined as a democratic and social federal State [1].

In Germany, in 1682, a decree on measures of state charity was adopted, and in 1748 and 1763, respectively, an edict and a rescript appeared to combat beggary. The heyday of charity in Germany falls at the beginning of the XX century, the coordinator of which was the "German Association of Public and Non-Governmental Support". The new laws "On Public Assistance to Young People" and "On compulsory Social security" have made it possible to unite the state, municipal levels and free associations [2].

In the middle of the XIX century, there was an experience of creating a unique non-state system 
CURRENT RESEARCH JOURNAL OF HISTORY 2(5): 37-41, May 2021

DOI: https://doi.org/10.37547/history-crjh-02-05-11

ISSN 2767-472X

(C)2021 Master Journals

\section{Crossref dof 81 Google}

Accepted 25th May, 2021 \& Published 31 ${ }^{\text {th }}$ May, 2021

of individual and selfless assistance to those in need. This system, characterized by strict order and thoughtful organization, was introduced in the city of Elberfeld in 1852. At its core, it contained the desire not only to provide shortterm assistance to the needy, but also to lift them out of poverty, as well as to promote the moral growth of both the well-off and the benefactor. One of the most important principles of the Elberfeld system was the belief that a detailed study of the social status of each applicant for social assistance was necessary. Management and coordination of assistance to the poor in Elberfeld was carried out by a special elected body (deputation), the head of which was the mayor. The deputation also consisted of 4 members of the city council and 4 representatives chosen from citizens. The entire city was divided into 31 districts, each of which had several voluntary trustees for the poor, who took care of 5-6 needy families.

Without dwelling on the details of the Elberfeld system, we note that it was implemented in Bremen, Lübeck, Dusseldorf, Munich, Frankfurt am Main and other cities in Germany and has shown its effectiveness everywhere [3]. By the end of the XIX century, Germany had established a legal framework for the system of mandatory social protection and insurance of workers employed in production. It included legislation on protection against disease (1883), disability and old age (1889), and on the harmful effects of production and accidents (1884). The second stage, which included the beginning of the late 20-60s of the XX century, determined the need for a serious approach and attention to the human factor in relation to the universal community of huge human reserves lost in the first and Second World Wars, namely, the development of universal criteria, principles, directions of measures for perfect social protection of the population [4].

Social assistance (Sozialhilfe) was introduced in
Germany in 1962.At that time, the recipients of various kinds of subsidies and benefits were 500 thousand people, which was about $1 \%$ of the population. The current objective of social assistance is to help the recipient achieve a decent standard of living (which includes providing food, housing, clothing, hygiene products, household goods, as well as providing them with the opportunity to participate fully in cultural life). The provision of assistance should help the recipient to gain financial independence, which he is obliged to promote to the best of his ability [5].

In the 70s of the XX century. in Germany, a largescale reform of social legislation was carried out. Currently, the main law is the "Federal Law on Social Assistance" (Bundessozialhilfegesetz), which regulates the rights and obligations of both the recipient of social assistance and the social agency, as well as the types of assistance provided and the relationship of the said agency with other agencies. Since 1975, 10 "Social Law Books" (Sozialgesetzbuch) have been published, regulating various legal situations and procedures. It should be noted that the" Agreement on Unification " (Einigungsvertrag) for the new lands (excluding Berlin) provides for special circumstances in which the action of the norms set out in the "Book of Social Laws" is limited to the actual available funds: the lack of funds in the city cash register of any of the new lands causes the payment of social assistance in a reduced form. It should be noted that the bureaucratic institutions of social protection were sharply criticized by sociologists of the Frankfurt School. For example, Yu. Habermas argued that " the 'system world' is replacing the 'life world', and formal relations with the state are replacing social responsibility and the joint activities of citizens" [6].

According to the current legislation, the State social Service (Sozialamt) is obliged to help every person who applies for help, provided that they 
CURRENT RESEARCH JOURNAL OF HISTORY 2(5): 37-41, May 2021

DOI: https://doi.org/10.37547/history-crjh-02-05-11

ISSN 2767-472X

(C)2021 Master Journals

\section{Crossref dof 81 Google}

Accepted 25th May, 2021 \& Published 31 th May, 2021

are registered in Germany. The object of charity, that is, non-state social assistance, can be the following categories of citizens:

- persons who do not have a registered place of residence (homeless people). There are about 30 thousand of them in the country for 83 million people;

- recipients of state social assistance when they first move into an apartment. They are assisted in purchasing furniture, electrical appliances, bed linen, curtains, etc. Furniture and electrical appliances (stove, refrigerator, washing machine, vacuum cleaner, TV) are paid only for secondhand, purchased in purchases or in warehouses of charitable organizations [7].

- persons who have been denied assistance by state social services for any reason, or persons in need of emergency support.

Thus, in Germany, the hypothetical register of potential beneficiaries is made up of representatives of the three socio-demographic groups mentioned above. The register of persons who actually received assistance is maintained in organizations that are engaged in charity. As our personal communication with representatives of the Deaconical Service of the Evangelical Church showed during the "Partnership Forum of Civil Societies of Russia and Germany on the land of Tatarstan", held in Kazan on August 15-22, 2010. at the initiative of the German House of the Republic of Tatarstan and the Ministry of Culture of the Republic of Tatarstan with the support of the Ministry of Regional Development of the Russian Federation, the basis for indirect coordination of charity is the applicant's membership in this public association, although there are exceptions.

The available published sources containing the information necessary for our research have made it possible to identify the largest charitable organizations in modern Germany.
1. Arbeiterwohlfart (AWO, "Workers' Charity " - is a charitable organization founded in 1919. Its Charter states that the AWO "is a politically independent and nondenominational union of public charity" (quoted in [7]). The specialized AWO centers carry out "activities in all areas of social work, from preventive assistance in distress situations to full social rehabilitation" [8].

2. Caritas, Deutscher Caritasverband (DCV, "Caritas") - a charitable organization of the Catholic Church in Germany, the creation of which dates back to 1897 , linking it with the name of the priest Lorenz Werthmann, secretary of the Archbishop of Freiburg. L. Werthmann organized the first diocesan coordination center in Germany, called "Caritas". One of the latest projects implemented by the Caritas Center in Germany was the project "Social Manners for a Better Society", aimed at helping people left without housing [9]. Currently, national Catholic charities operate in approximately 200 countries around the world.

3. Diakonisches Werk, Diakonisches Werk der Ewangelischen Kirche - DW, Deaconical Service) - a charitable organization of the Evangelical Church, formed in 1848 at the Wittenberg Church Cathedral. The program of the organization was the speech of Johann Hinrich Wichern "Internal mission against spiritual and material poverty and social disadvantage" [10]. About 12,000 church parishes and hundreds of thousands of volunteers support the work of deaconical services. The highest governing body of the Deaconess Service is the Deaconess Conference, headquartered in Stuttgart.

4. The fourth subject of charity in modern Germany is charitable foundations created by individuals or legal entities. As a rule, the material basis of a charitable foundation is 
real estate or cash, but for charitable purposes, not the main "funds" themselves are used, but the dividends earned on their basis" [11].

In Germany, it is generally accepted that charitable organizations that are "worthy" of investing money in them must meet the following requirements [12]:

- registration with the UN as a nongovernmental organization or the presence of an official representative from among celebrities;

- the absence of spending "on yourself" among your charitable goals»;

- transparency of functioning; - availability of the program;

- detailed formulation of the goals of the organization's activities;

- lack of elements of manipulation when working with the population ("pressure on pity»);

- providing all its representatives with the appropriate certificates;

- respectful attitude of the organization's representatives to potential donors;

- providing potential donors with written information about the organization's activities;

- issuance of appropriate confirmations to donors for submission to the tax office -

- issuance of sealed mugs for donations to representatives of the organization (in the case of collecting cash) [12].

5. The fifth subject of charity in Germany should be considered volunteers. Volunteers are volunteers who perform certain work without the expectation of remuneration. According to the observations of the head of the laboratory of problems of vocational education of persons with
Disabilities of the Research Institute for the Development of Vocational Education at the Department of Education of Moscow, A. Ya. "In Germany, these are mostly pensioners, but sometimes they are housewives or students who are financially well-off and want to bring public benefit, take up free time, solve communication problems. They come through ads or on their own initiative and work in good faith on a free but necessarily responsible basis. Volunteers help in hospitals and nursing homes, work with children, participate in environmental programs, and work in public organizations. These are respected people who feel public recognition" [10].

Thus, the most significant charitable activities in modern Germany are five subjects, three of which are large public associationsArbeiterwohlfart, Caritas, Diakonisches Werk. As the names suggest, the main task of the first of these organizations (Arbeiterwohlfart) is to provide charitable support to workers and their families, the other two help those in need mainly on the basis of their religious affiliation. In the activities of charitable foundations, it is necessary to pay attention to the mechanism of formation and expenditure of funds: the use of interest on the fixed capital for charitable purposes, but not the capital itself. Volunteer activities are notable for the active participation of the elderly.

\section{Conclusions}

In conclusion, it should be noted about the nature, regulatory system and main structures of charitable activities in modern Germany, which allowed us to determine the main elements of the model of its coordination and their functions. And so, in modern Germany, despite the high degree of state social support for the population, there is a private and public charity with a significant role of volunteerism. Charitable 
CURRENT RESEARCH JOURNAL OF HISTORY 2(5): 37-41, May 2021

DOI: https://doi.org/10.37547/history-crjh-02-05-11

ISSN 2767-472X

(C)2021 Master Journals

Crossref doi 8 Google

Accepted 25th May, 2021 \& Published 31 th May, 2021

activity is considered as an auxiliary social mechanism. The object base in comparison with the total population is relatively small, and the subject base is extensive. Coordination of practical charitable activities is carried out mainly at the level of federal lands, communities and grassroots structures of charitable organizations.

\section{REFERENCES}

1. Fundamentals of Constitutional Law in Germany. - URL: http://www.econsafety.ru/academ/ kaf/gpd/AUK/tex15.html, free.

2. Vysotskikh, I. K. History of charity development in Russia in the Soviet and post-Soviet periods (historiographic essay) / I. K. Vysotskikh // Bulletin of the Udmurt University. Series "History and Philology". 2014. - No. 1. [Electronic resource]. Electron. dan. - Access mode: https://cyberleninka.ru/article/n/istoriyarazvitiya-blagotvoritelnosti-v-rossii-vsovetskiy-i-postsovetskiy-periodyistoriograficheskiy-ocherk (accessed: 19.05.2018).

3. Nekrasov A. Ya. Charity // Encyclopedic Dictionary of F. A. Brockhaus and I. A. Efron: in 86 volumes. - St. Petersburg: I. A. Efron's Printing House, 1891. - Vol. 4. - pp. 55-58.

4. Abdullaev D. History of development of charity and sponsorship in Uzbekistan. Tashkent "innovation-Ziya" 2019. - p. 22.

5. Rabinovich. Social assistance in Germany. 2002. - URL: http://www.vorota.de/ web455. AxCMS, free.

6. Habermas $\mathrm{Yu}$. Relations between the system and the life world in the conditions of late capitalism // Theory and History of economic and social institutions and systems. - 1993. - Vol. 1, Issue 2. - P. 123-
136.

7. Madievsky S. A. Social assistance in Germany. "Seagull" (Seagull). - 2003. - № 9 (9). - 21 nov. - URL: http://www.chayka.org/article.

8. Ismailov B. I. Genesis of legal regulation of charity, philanthropy in the law enforcement practice of foreign states. Library.by (Belarusian Digital Library). - 2007. - URL: http://library.by/portalus/modules/politics /

9. "Caritas" in Germany calls for respect for people who have found themselves below the poverty line as a result of the crisis // Christian News and news of religions from around the world. - 2009. - 19 Jan. - URL: http://www.maranatha.org.ua/cnews/r/52 878 , free.

10. Ismailov B. I. Genesis of legal regulation of charity, philanthropy in the law enforcement practice of foreign states. Library.by (Belarusian Digital Library). - 2007. - URL: http://library.by/portalus/modules/politics /

11. Mindel A. Ya. Integration into the world community: The German experience. - URL: http://www.mosniirpo.ru/index.php?option $=$ com_content\&task=view\&id=307, free.

12. Orlova $E$. The $A B C$ of charity. Winter holidays - time of active collection of donations / / Europe-Express. - 2006. - № 1 (409). - 2 Jan. - URL: http://www. euxpress.de/archive/artikel_617.html, free. 